\title{
Burying the 'Power Few': Language and Resistance to Evidence-Based Policing
}

\author{
Lawrence W. Sherman ${ }^{1}$
}

Published online: 24 October 2019

(C) Springer Nature Switzerland AG 2019

The aim of this essay is to bury the concept of 'power few' offenders in evidence-based policing (Sherman 2007). The essay provides a case study in the presentation of research for a broad dialogue about policing. The case study addresses the larger issue of language and resistance in the application of science to everyday life, from vaccination for measles to evidence-based policing.

As a victim of its own success, the concept of a 'power few' subset of people causing (or suffering) the majority of crime harm has been used in a growing number of studies (Bland and Ariel 2015; Dudfield et al. 2017). Yet as the concept makes contact with the wider world of dialogue beyond police professionals, the name has provoked emotional reactions that threaten the entire enterprise of evidence-based policing. In order to save the concept of a 'power few', and its application, it is time to change the concept's name.

\section{A Call-in Radio Show in Western Australia}

The evidence for this conclusion is not strong, but it is powerful. It begins with a 2016 report to the Western Australia Police (Sherman et al. 2016), which was originally entitled 'Targeting Family Violence Reported to Western Australia Police, 2010-2015: the Power Few.' On the weekday that the report was released, then-Deputy Commissioner Stephen Brown was invited to appear on a call-in radio show during morning drive-time. After he explained the huge concentration of harm (over 50\%) from family violence attributed to only $2 \%$ of all recorded offenders in that category, the Deputy Commissioner described those most harmful offenders as the 'power few'. When he took call-in questions from the radio audience, a male caller objected to the way in

Electronic supplementary material The online version of this article (https://doi.org/10.1007/s41887-01900038-8) contains supplementary material, which is available to authorized users.

Lawrence W. Sherman

Lawrence.Sherman@crim.cam.ac.uk

1 Cambridge Centre for Evidence-Based Policing, Somersham House, Rectory Lane,

Cambridgeshire PE28 3EL, UK 
which the most harmful offenders were described. Calling that group of abusers a 'power few', the caller said, implied they were deserving of praise or respect, as in a sports context. He argued that they should be called a name that provided an appropriate condemnation of their severe and criminal conduct.

This is how the report to WA Police described the 'power few':

Across 214,814 cases reported to WA Police [in 2010-15], with a total of 36,228 offenders, just two percent of them caused over fifty percent of the days in prison associated with their crimes using the Cambridge University 'crime harm index' (CHI). Taken as a whole, this group committed or attempted murder at the rate of 2,000 per 100,000 per year, as compared to just 1.68 per 100,000 per year for the state as a whole.

On that basis, the first author of the report was happy to agree with the caller - and with the Deputy Police Commissioner, who asked that the subtitle of the report be changed. The new subtitle was 'the Felonious Few and the Miscreant Many'. The language throughout the report was changed as well, to avoid confusing the public about whether the few were to be respected or condemned. Since the point of producing the evidence was to educate both police and the public as to the nature of the problem, the decision was quickly made.

There was, after all, no particular public education reason to call this group a 'power' few. Rather, Sherman (2007) had taken the concept from the field of statistics, in which a 'power curve' shows a highly skewed distribution (Pareto and Page 1971). In such a distribution, there is a concentration of a lot of something (anything) among a very small percentage of all of the units that could have any amount of that something. In the original analysis by Vilfredo Pareto (b. 1848, d. 1923) case, the 'something' was ownership of $80 \%$ of land in Italy, and the units of ownership were the $20 \%$ of landowners in Italy who held the $80 \%$ of land. The fact that the basic idea for a 'power few' had come from economics makes recent developments in that field even more relevant to the use of language in applied social science.

\section{Science and Simplicity in Economics}

Further evidence for the need to bury the name 'power few' comes from recent developments in the economics of inequality, a century after Pareto's work in the early twentieth century. Pareto's Italian contemporary, Corrado Gini (b.1884, d.1965), created an index of inequality, broadly defined as the average discrepancy in wealth (or income, or anything of value or even harm) between each person in a society and all others. The coefficient for this index is widely used to measure trends and patterns of inequality in wealth within and across nations, over time. Yet very few people would understand it. Few headlines have ever said 'Gini Index Rising Rapidly', even though it has, in both the USA and the UK, in the decades since 1980.

In order to further public education about income inequality, recent work by French economists has tried to use clearer concepts to describe the phenomenon. As a recent review of inequality research in a general readership magazine reports, Thomas Piketty, 
Francois Bourguignon and Emmanuel Saez, among others, have attracted a great deal of public attention by using new language (Ahamed 2019: 29):

They consciously moved away from quantifying inequality with opaque statistics such as the Gini coefficient, and instead popularized more readily understandable measures, like the share of income going to the very, very rich. The phrases 'top one percent' and its obverse, 'the ninety-nine percent' became potent political rallying cries during the Occupy Wall Street movement in 2011.

This fact is admittedly weak evidence, but it describes a huge effect. As the author observes, an entire US presidential race may centre on how well the candidates deploy the language of inequality, as well as their narrative about who to blame and what solutions to adopt. Much of that narrative will appeal to issues of identity, which are themselves an important dimension of the emotional overtones of evidence-based decision-making among police and the wider public.

\section{Vaccines, Culture Wars and Identity}

Central to the skill in using language is the principle that the meaning of words is socially constructed, and can change over time. This means that there is no 'objective' meaning of a concept like the 'power few', or even the felonious few. Conflict and struggle for control in society is often carried out by creating new meanings for existing words, or even new words that were opaque to begin with. Thus, for a third plank of evidence for burying the concept of the 'power few offenders', we turn to the socially constructed demonization of cows.

The word 'vaccine' is derived from the Latin word 'Vaccinus', which means 'cow'. The reason that cows were linked to medicine is that British doctor Edward Jenner (b. 1749, d. 1823) discovered that dairy maids who milked cows often contracted cowpox, but never smallpox. Since the effect of cowpox was mild, and the effect of smallpox was deadly, Jenner deduced that infecting humans with active cowpox could immunize them from contracting smallpox. Jenner's self-published book (Jenner 1798) reported on his initial tests and attracted funding from the Crown to promote the use of 'his vaccine'. In 1978, the World Health Organization declared smallpox to be extinct. But that victory did not come without a long struggle, as historian Williams (2019) recently reported:

By the time Jenner died in 1823, millions had come to regard him as a hero..... But not everyone thought Jenner was a saint. In 1858 Prince Albert unveiled a statue to Jenner in Trafalgar Square, amid much pomp and circumstance. There was such an outcry that two years later the statue was carted away to a lower-key resting place in Kensington Gardens. Jenner's earliest and most vocal opponents had been men of the church, who reasoned that smallpox was a God-given fact of life and death. If the Almighty had decided that someone would be smitten by smallpox, then any attempt to subvert this divine intention was blasphemy. 
Vaccination was also bestial, because humans were being poisoned with disgusting stuff from an animal. Even religious people subscribed to the view that smallpox was a force for good because it tended to cull the children of the poor: if vaccination were allowed to take hold, society would quickly be overrun by the lower classes.

While smallpox was defeated, measles remains a killer-at the rate of about 1 per thousand - with more recent deaths in the Democratic Republic of the Congo than from the Ebola virus. The recent resurgence of measles in Europe and the USA is attributed to the 'anti-vaxxer' movement, which can safely be described as opposing evidencebased medicine. A major leader of that movement, not surprisingly, was himself trained as a medical doctor, Andrew Wakefield.

Wakefield is the British gastroenterologist who produced the notorious article, published in The Lancet in 1998, linking the M.M.R. vaccine to autism. The study, which featured just twelve subjects, was debunked, the article was pulled, and Wakefield lost his license to practice medicine - as well as his reputation, in scientific circles anyway. But, owing to his persistence in the years since, his discredited allegations have spread like mold. (Paumgarten 2019)

In 2016, Wakefield produced a widely viewed documentary called 'Vaxxed', which purports to prove a government cover-up of the truth about measles vaccine causing autism. The use of the terms 'vaxxed', or 'vaxxers', seems successful in persuading uncertain people that vaccines are harmful and should be avoided. This documentary, and its language, may be one reason why the UK went off the measles elimination list in 2018, after years without any measles cases (Paumgarten 2019).

Quite apart from the language of science, we must also reckon with belief in science itself. The centre of the New York state measles epidemic in the past year was in upstate New York, in an Orthodox Jewish community with low rates of anti-measles vaccination. While the Rabbis in the community did not oppose vaccination - and even encouraged parents to vaccinate their children - the culture of the community was such that many people were not comfortable with vaccination. The general nature of this problem has been suggested by a scientist who studies the social 'virus' of vaccine refusal:

Elisa Sobo, a medical anthropologist at San Diego State University, has advanced the idea that saying no to vaccinations is as much an opting in as it is an opting out- 'like getting a gang tattoo, slipping on a wedding ring, or binge-watching a popular streamed TV show,' she writes, in a recent paper, 'Theorizing (Vaccine) Refusal.' 'This kind of refusal is more about who one is and with whom one identifies than who one isn't or whom one opposes.' (Paumgarten 2019)

If saying no to vaccines is a symbol of identity, then what about saying no to evidencebased policing? Does saying yes to EBP mean that you admit you are not a real cop? Does saying no mean that you, like an anti-vaxxer, are allied with a tradition that refuses to trust authority? As Williams (2019) notes, there was, in fact, good reason in 
the first century of smallpox vaccinations to distrust the authority of doctors, especially before the advent of germ theory. For centuries, the antinomian tradition of making decisions based on feelings and an inner voice has proved a major force for noncompliance, with policies both good and bad (Sherman 2001). An identity as someone who decides what is right based on their heart is a powerful force. It may or may not be relevant to quantitative calculations based on numbers. But once those numbers are turned into words, they risk provoking a negative reaction: That phrase the 'power few' just doesn't seem right.

In some police agencies, identifying with EBP has been a matter of career success or failure. It has required an all-or-nothing commitment to preferring evidence to support decisions, rather than preferring to make major decisions without evidence, which might 'stop you from doing what you want to do,' as one high police official recently put it to a criminologist embedded in his agency. In order to spread support for at least considering evidence relevant to strategic decisions, research for evidence-based policing seems well advised to consider any evidence that its terminology makes anyone feel as if EBP is 'wrong'.

This point is even more important, given the evidence about the segmentation of the families that do not accept measles vaccination for their children (Paumgarten 2019). Students of the social 'anti-vaccine virus' distinguish between 'die-hard refuseniks' and the 'vaccine-hesitant'. As one measles vaccine advocate put it, the 'hesitant' parents are a softer target: '..the yes-but set, whose heads are aswirl with contradictory information, and who really want nothing more than for their children to be healthy and safe' (Paumgarten 2019). Perhaps the main target for promoting evidence-based policing should be the 'yes-but set', who want to do the best thing for the public interest but are emotionally uneasy about a science-based approach. The last thing EBP advocates should do, perhaps, is to make 'yes-but' colleagues or citizens even more uneasy with terms like the 'power few'.

Like public education about inequality, the example of vaccines fails to provide strong evidence to bury the 'power few'. What it provides is material for lateral thinking. Both cases support the story of the radio listener from Western Australia, at the most basic level. Instead of working in a 'bubble' in which professionals talk to each other using precise language they all understand, anyone in contact with a wider ('lay') audience must sacrifice such precision for public comprehension. Knowing about the 'power few' has been a kind of password for joining conversations about EBP. Public education, however, requires a broader reach.

\section{Naming the Few: High-Harm Places, Victims and Offenders}

In reporting the first comprehensive analysis of all detected offenders in one police jurisdiction over a 7-year period, Liggins et al. (2019) show the great importance of identifying priority offenders based on both volume and severity of crime. The Northamptonshire Police analysis, based on over 327,000 crimes and almost 40,000 suspects, shows an astonishing concentration of $80 \%$ of all crime harm in just $7 \%$ of all detected offenders. While most of that felonious few de-escalated the seriousness of their offending over time, a very small portion of them persisted from year to year in the highest harm levels. 
The Liggins-led work provides the foundation for more digital innovations in tracking offenders, as well as targeting them with the most precise priorities available in policing to date. Ideally, the work should be replicated in police forces across the UK, with an eye to operational updating of the rank order of offending harm on a dayby-day basis.

The Northamptonshire work builds on a tradition that arguably began with the Philadelphia Birth Cohort study's discovery of a concentration in the number of offences within a small group of the offenders (Wolfgang et al. 1987). That concentration inspired other searches for concentrations, which Sherman (2007) summarized as all fitting a pattern that would allow the targeting of crime-reduction efforts on a 'power few' of places, victims and offenders. In her Cambridge master's thesis that was the basis of the 2019 article, Liggins used the term 'power few' for the first time on the basis of a crime harm index calculation.

By publishing the article in this journal with the term 'felonious few', Liggins et al. (2019) become the first to our knowledge to use that language in an international journal. The Journal is grateful for the authors' agreement to do so. As a matter of editorial policy, this journal will continue to ask authors to use that phrase, rather than the 'power few', to describe offenders to whom over half of all crimes, or crime harm, is attributed.

Similarly, we will ask authors of research on the concentration of harm among victims to use the more neutral terminology of 'high-priority victims' to describe the most harmed (as in Dudfield et al. 2017). As for studies on targeting high-harm or highcrime volume locations, we see no reason to avoid using 'harm spots' or 'hot spots' as the terminology, or even a 'power few' subset of hot spots where most crime or harm is concentrated. Places do not have as much moral status as people, so this policy may work well. We remain open, however, to any evidence that any of this language undermines the readiness of people to listen to what the research shows.

Words matter. So does evidence. Let us continue to track our legitimacy among our many audiences, and to respond to their feedback, both qualitative and quantitative. Doing that is simply one more application of the Triple- $T$ of evidence-based policing.

\section{References}

Ahamed, L. (2019). Widening Gyre: the rise and fall and rise of economic inequality. The New Yorker, 2, 2629.

Bland, M., \& Ariel, B. (2015). Targeting escalation in reported domestic abuse: Evidence from 36,000 callouts. International criminal justice review, 25(1), 30-35.

Dudfield, G., Angel, C., Sherman, L. W., \& Torrence, S. (2017). The "power curve" of victim harm: targeting the distribution of crime harm index values across all victims and repeat victims over 1 year. Cambridge Journal of Evidence-Based Policing, 1(1), 38-58.

Jenner, E. (1798). An inquiry into the effects of Variolae Vaccinae, a disease discovered in some of the western counties of England, particularly Gloucestershire, and known by the name of The Cow Pox. London: Sampson Low, Printer.

Liggins, A., Ratcliffe, J. E., \& Bland, M. (2019). Targeting the most harmful offenders for an English police agency: continuity and change in members of the "felonious few". Cambridge Journal of Evidence-Based Policing, 3, 3 .

Pareto, V., \& Page, A. N. (1971). Translation of Manuale di economia politica ("Manual of political economy"), A. M. Kelley, ISBN 978-0-678-00881-2.

Paumgarten, N. (2019). The message of measles. The New Yorker September, 2, 38-47. 
Sherman, L. W. (2001). Two protestant ethics and the spirit of restoration. In H. Strang \& J. Braithwaite (Eds.), Restorative Justice and Civil Society (pp. 35-55). Cambridge: Cambridge University Press.

Sherman, L. W. (2007). The power few: experimental criminology and the reduction of harm. Journal of Experimental Criminology, 3.4(2007), 299-321.

Sherman, L. W., Bland, M., House, P., \& Strang, H. (2016). Targeting family violence reported to Western Australia police, 2010-2015: the felonious few vs. the miscreant many. Cambridgeshire: Cambridge Centre for Evidence-Based Policing Ltd Online at.

Williams, G. (2019). The original anti-vaxxers: how Edward Jenner contributed to Today's culture wars. The Economist online, 30th August.

Wolfgang, M. E., Figlio, R. M., \& Sellin, T. (1987). Delinquency in a birth cohort. Chicago: University of Chicago Press.

Publisher's Note Springer Nature remains neutral with regard to jurisdictional claims in published maps and institutional affiliations. 